\title{
DEPOSITION OF ENVIRONMENTAL CONTAMINANT IN PROCESSED BUSHMEAT ALONG HIGHWAYS IN SOUTH-WESTERN NIGERIA
}

UDC 546.3/.9:613.281:625.7(662.6)

\author{
Ogunjobi Johnson Adedayo ${ }^{1}$, Thompson Faraday Ediagbonya ${ }^{2}$ \\ ${ }^{1}$ Dept of Biological Sciences, Ondo State University of Science and Technology, \\ Okitipupa, Nigeria \\ ${ }^{2}$ Dept of Chemical Sciences, Ondo State University of Science and Technology, \\ Okitipupa, Nigeria
}

\begin{abstract}
A study was conducted to investigate deposition of environmental contaminants in bushmeat with emphasis on some heavy metals \{Nickel (Ni), Lead (Pb), Cupper (Cu) and Cadmium $(C d)$ \}. The major bushmeat markets on these highways were studied in terms of their distance to the highways, traffic volume (TV) and land uses. Face-to-face interview was also conducted with one hundred and twenty processed bushmeat buyers on these highways to determine the most commonly preferred processed bushmeat while the concentrations of $\mathrm{Ni}, \mathrm{Pb}, \mathrm{Cu}$ and $\mathrm{Cd}$ in the three most commonly purchase processed bushmeat identified were determined using Atomic Absorption Spectrophotometry. It was revealed that the average distance of the market at IIbadan-Lagos (IL)Ibadan-Ife (IF), Ore-Sagamu (OS) and Abeokuta-Ibadan (AI)\} were $6.70 \mathrm{~m}, 3.50 \mathrm{~m}$ and $10.20 \mathrm{~m}$, respectively. TV followed $I L>O S>I F>A I$ trend. Heavy metals examined were present in the three commonly purchased processed bushmeat (Grasscutter, Duiker and Monitor-lizard) at varying levels. $\mathrm{Pb}$ concentration in grasscutter $(0.01 \pm 0.01 \mathrm{mg} / \mathrm{kg})$ at $\mathrm{OS}$ was lower than the maximum permissible level (MPL) while the concentrations of $\mathrm{Ni}$, and $\mathrm{Cd}$ in duiker at IF $(0.06 \pm 0.09 \mathrm{mg} / \mathrm{kg})$ and $A L(0.06 \pm 0.05 \mathrm{mg} / \mathrm{kg})$, respectively were higher than the MPL. The concentrations of the verified heavy metal in these bushmeat had significant effects $(p<0.05)$ on the distance.
\end{abstract}

Key words: Bushmeat, heavy metals, pathway, highways, ecotoxicology

Received March 3, 2017 / Accepted January 12, 2018

Corresponding author: Ogunjobi Johnson Adedayo

Ondo State University of Science and Technology, Okitipupa, Ondo State

E-mail: ogunjonson02@gmail.com 


\section{INTRODUCTION}

Unsustainable hunting of wildlife in South-western Nigeria is fast threatening nontimber forest products especially bushmeat, considering the actions driven by continuous demand for the product particularly among the travelers on highways. Ogunjobi et al. (2013) reported that the persistent indiscriminate collection of biological resources of either plant or animal origin in the developing countries, particularly in the tropical region of the world, continues to generate a lot of new idea or innovation, perhaps due to its unselective consequences on human being which may be hazardous and uneconomical to abate. Irrespective of geographical location of man, highways serve as essential amenity for easy movement of people and goods from one location to the other. Highways in tropical areas are well known to bring open access to remote areas for agricultural development, and resource extraction (Arima et al. 2005; Caldas et al. 2010), and facilitate development by providing market access for rural producers, integrating economic sectors and reducing the cost of spatial mobility (Perz et al. 2007).

Despite various benefits of highways to mankind, using them often results in negative impacts on the environment (Forman and Alexander 1998; Spellerberg 1998; Fahrig and Rytwinski 2009; Perz et al. 2012). An eample of such impact of highways is the introduction of pollutants (Forman and Alexander 1998; Keller and Largiader 2003; Laurance et al. 2004; Shyama Prasad Rao and Saptha Girish 2007). In Nigeria, some highways are either constantly or seasonally used to display many non-timber forest products, particularly bushmeat. Bushmeat is the meat obtained from wild animals for consumption due to their protein source (Bowen-Jones et al. 2003; Martin 1983). According to Juste et al. (1995) who postulated that wild animals such as primates, antelopes, porcupine, bush-pig, grasscutter, pangolin, monitor lizard, guinea fowl, among others are valued food by many urban dwellers. Moving along the highways, many anthropogenic activities take place on a daily basis and its consequential effect could be devastating to the physiological condition of man.

Bai et al. (2009) and Li et al. (2001) informed that exhaust of the vehicles resulting from the combustion of fuel was one of the causes of environmental pollution along the highways. Environmental pollutants include a wide range of chemicals present in products that are used by man on a daily basis (Rhind et al. 2010). To achieve sustainable food security in an era of geometric increase in human population, proper integration of non-timber forest products into food system is required. Food systems, as illustrated by Erickson (2008), involve the activities related to food production, processing, distribution, preparation and consumption of food. Vehicle exhausts emit heavy metals so that soils, plants and even residents along the roads with heavy traffic loads are subjected to increasing levels of heavy metal contamination (Ghrefat and Yusuf 2006). Regrettably, excess of these heavy metals beyond stipulated maximum permissible level is hazardous irrespective of the host (Gray et al. 2003; Bai et al. 2009). It was mentioned that some of these heavy metals are cumulative poisons that pose potential hazards and toxicity (Ellen et al. 1990; Jarup 2003). The risks associated with the exposure to heavy metals present in food products have aroused widespread concern in human health (Nkansah and Ansah 2014). Emissions from road traffic that uses fossil fuel, industry, agriculture, sewage sludge, and waste incineration was declared as the chief sources of air pollution (Celik et al. 2005; Ediagbonya et al. 2016). 
It was reported that food absorbed heavy metals from polluted environments (ZureraCosano et al. 1989) and these metal may enter human body through consumption of contaminated food (Cambra et al. 1999). Contamination of food with heavy metals is a serious threat because of their toxicity and bioaccumulation in the food chain (Demirezen and Uruc 2006). Heavy metal becomes toxic when they are not metabolized by the body and accumulate in tissues (WHO 2011). It was reported that bitumen and mineral filler materials in the asphalt road surfaces contain different heavy metals including $\mathrm{Cu}, \mathrm{Zn}, \mathrm{Cd}$ and $\mathrm{Pb}$ (Pope 2006). Emission from heavy traffic were reported to contain Lead $(\mathrm{Pb})$, Cadmium (Cd), Zinc (Zn), and Nickel which are present in fuel (Suzuki et al. 2008; Atayese et al. 2009; Ediagbonya et al. 2014).

Since ecosystem-based management recognises that people are part of the ecosystem and that the protection of ecosystem integrity includes the well-being of human, to identify significant environmental contaminants capable of disrupting ecosystem should as a matter of urgency be a topical issue. Undoubtedly, quantitative investigation of heavy metal such as nickel, lead, copper and cadmium in processed bushmeat displayed along major highways in South-western Nigeria will be very helpful to determine ecotoxicological effects of displaying consumable goods near to the road and also give direction in tackling food poisoning that may be linked with meat from wildlife origin.

\section{MATERIALS AND METHOD}

South-western part of Nigeria comprises of six states viz.: Oyo, Ondo, Ogun, Osun, Ekiti and Lagos States (Figure 1). Only four out of these states (Oyo, Ondo, Ogun and Osun) was surveyed in this study. For better and accurate research execution, the study was divided into four stages. The first stage of the study lasted for seven months (December, 2013 to July, 2014). During this stage, one bushmeat market along the highway with high patronage of travellers in each of the four selected states was considered. The major difference across the bushmeat markets during our survey were the distance (used as the only factor in the study) of the markets to the highway that was measured with meter tape. Traffic volume (TV) was also recorded across the study area.

In the second stage of this study which lasted for four months (October 2014 to July 2015 ), each of the study sites were visited twenty times between the hours of $12.00-$ $4.00 \mathrm{pm}$. During this period, face-to-face interview was conducted with thirty (30) buyers of processed bushmeat purposively selected from each study area based on their readiness to supply needed information and computed to determine the commonly processed bushmeat. Methods of singeing the animals across the four sites were also observed but not considered as a factor.

Third stage of this study was the collection and proper labelling samples of the three most commonly purchased bushmeat across the four sites. In the laboratory, each sample $(2.0 \mathrm{~g})$ was put into digestion tubes and mixed with $10 \mathrm{ml}$ each of nitric acid and perchloric acid. The digestion block was activated for three hours at $45^{\circ} \mathrm{C}$. The digested samples were cooled, diluted to $100 \mathrm{ml}$ with distilled water and filtered into sample bottles. Quantitative examination of heavy metal in each sample was using Atomic Absorption Spectrophotometry (Perkin Elmer Analyst 300). Data generated were analyzed using descriptive statistics, and one-way Analysis of Variance while the significant differences between the means were determined using the LSD test. 


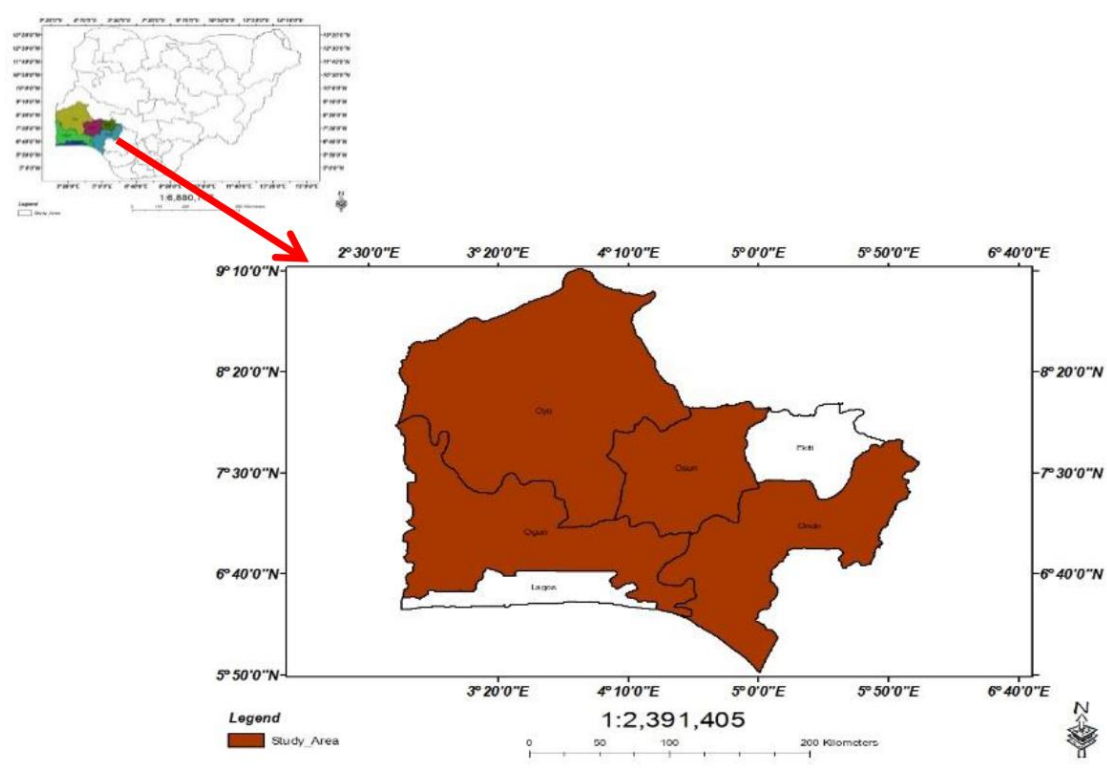

Fig. 1 Location of south-western States in Nigeria and the study area

\section{RESULTS AND DISCUSSION}

\subsection{Description of Bushmeat Selling Points in South western Nigeria}

Reconnaissance survey was conducted to identify bushmeat markets and processing points in South-western Nigeria as shown in Table 1. It was revealed that bushmeat market at IF are at an average distance of $3.50 \mathrm{~m}$ distance to the highway followed by AI $(5.80 \mathrm{~m})$, IL $(6.70 \mathrm{~m})$ and OS $(10.2 \mathrm{~m})$. Movement of dust particles particularly during overtaken on unpaved roads was noticed. A lot of dust experience on these highways agreed with the submission of Farmer (1991) who stated that unpaved roads are particularly important sources of dust pollution. There was no mechanism to determine the actual number of vehicles that passed through these roads during our study. Notwithstanding, our visual observation and counting revealed that the TV followed (IL $>\mathrm{OS}>\mathrm{IF}>\mathrm{AI}$ ) trend and processed bushmeat displayed very close to the highways were more exposed to dust particles. Table 2 described the trend of processed bushmeat commonly purchased during this study. Generally, larger proportion of processed bushmeat are purchased at OS (326) followed by IF (319), IL (241) and AI (192). In terms of species diversity, grasscutter was the highest (326) followed by duiker (294), monitor-lizard (190), bushbuck (161) and brush-tailed porcupine (91). Our findings on the bushmeat commonly purchased agreed with the position of many scholars (Onadeko 1996; Tee et al. 2012; Adewumi et al. 2013; Adefalu et al. 2014) where they ranked antelopes, grasscutter and monitor-lizard high among different species of commonly consumed in some parts of Nigeria. 
Table 1 Description of selected smoked Bushmeat markets

\begin{tabular}{|c|c|c|c|c|c|c|c|}
\hline \multirow{2}{*}{$\begin{array}{l}\text { Sites } \\
\text { Toll-gate }\end{array}$} & \multirow{2}{*}{$\begin{array}{c}\text { State of } \\
\text { Location } \\
\text { Oyo }\end{array}$} & \multicolumn{2}{|c|}{ Highway routes } & \multicolumn{2}{|c|}{$\begin{array}{l}\text { Average distance of } \\
\text { displayed Bushmeat } \\
\text { products to the highways }\end{array}$} & \multicolumn{2}{|c|}{ Land uses } \\
\hline & & \multicolumn{2}{|c|}{ Ibadan-Lagos(IL) } & \multicolumn{2}{|c|}{$6.70 \mathrm{~m}$} & \multicolumn{2}{|c|}{$\begin{array}{l}\text { IIA, SPRA, HT, } \\
\text { ICA, LIA }\end{array}$} \\
\hline Iyana-Ikoyi & Osun & \multicolumn{2}{|c|}{ Ibadan-Ife (IF) } & \multicolumn{2}{|r|}{$3.50 \mathrm{~m}$} & \multicolumn{2}{|c|}{$\begin{array}{l}\text { SPRA, HT, NCA, } \\
\text { NIA, HT, FCA }\end{array}$} \\
\hline Omotosho & Ondo & \multicolumn{2}{|c|}{ Ore-Sagamu (OS) } & \multicolumn{2}{|r|}{$10.20 \mathrm{~m}$} & \multicolumn{2}{|c|}{ SPRA, HT, ACA } \\
\hline Kila & Ogun & \multicolumn{2}{|c|}{ Abeokuka-Ibadan (AI } & \multicolumn{2}{|c|}{ I) $\quad 5.80 \mathrm{~m}$} & \multicolumn{2}{|c|}{ SPRA, LT, ACA } \\
\hline \multicolumn{8}{|c|}{$\begin{array}{c}\text { IIA - In Industrial Area, SPRA - Sparsely populated Residential Area, HT - High Traffic, } \\
\text { LT - Low Traffic, ICA - In Commercial Area, NCA - Near Commercial Area, } \\
\text { ACA - Away from Commercial Area }\end{array}$} \\
\hline $\begin{array}{l}\text { Common } \\
\text { name }\end{array}$ & $\begin{array}{r}\text { Scie } \\
\text { na }\end{array}$ & $\begin{array}{l}\text { entific } \\
\text { mes }\end{array}$ & OS & IF & IL & AI & Rank \\
\hline Duiker & $\begin{array}{r}\text { Ceph } \\
s\end{array}$ & $\begin{array}{l}\text { aloplus } \\
\text { pp }\end{array}$ & $83(25.86)$ & $109(34.17)$ & $68(28.22)$ & $34(17.71)$ & $2^{\text {nd }}$ \\
\hline Grasscutter & $\begin{array}{l}\text { Thrye } \\
\text { swind }\end{array}$ & $\begin{array}{l}\text { onomys } \\
\text { erianus }\end{array}$ & $98(30.50)$ & $73(22.88)$ & $82(34.03)$ & $73(38.02)$ & $1^{\text {st }}$ \\
\hline $\begin{array}{l}\text { Brush-tailed } \\
\text { porcupine }\end{array}$ & $\begin{array}{l}\text { Athe } \\
\text { afri }\end{array}$ & $\begin{array}{l}\text { erurus } \\
\text { canus }\end{array}$ & $29(9.03)$ & $21(6.58)$ & $31(12.86)$ & $10(5.21)$ & $5^{\text {th }}$ \\
\hline Bushbuck & $\begin{array}{r}\text { Trage } \\
\text { scr }\end{array}$ & $\begin{array}{l}\text { elaphus } \\
\text { iptus }\end{array}$ & $62(19.32)$ & $54(16.93)$ & $15(6.22)$ & $41(21.35)$ & $4^{\text {th }}$ \\
\hline $\begin{array}{l}\text { Monitor- } \\
\text { lizard }\end{array}$ & & ranus & $49(15.26)$ & $62(19.44)$ & 45 (18.67) & $34(17.71)$ & $3 r d$ \\
\hline Total & & & $321(100)$ & $319(100)$ & $241(100)$ & $192(100)$ & \\
\hline
\end{tabular}

For the fact that these animals are already cut into parts, it was impossible to determine their sexes. Singeing (the remover of animal hair) is basically done either by the use of flame in form of smoking or use of boiled water in form of steaming. As monitored, application of flame was common with the bigger game (bushbuck) and moderate size game (duiker) compared to what was observed in the case of grasscutter and monitor lizard. However, none of these animal species were exempted for smoking. Our observation also revealed that the flames used were fuelled majorly by wood with small proportion of dried grasses, used plastics and nylon materials. This was in line with the observation of Ekenma et al. (2014) where they mentioned that bushmeat vendors and cattle hides vendors, respectively uses various substances/methods in singeing off the hair of the animals. The concentration contents of heavy metal observed in this study can also be linked to the methods of processing as reported (WHO 2000; Stołyhwo and Sikorski 2005; Ishizaki et al. 2010). 
Table 3 Concentration of selected heavy metals in processed bushmeat commonly purchased in the study area

\begin{tabular}{llcccc}
\hline Locations & Sampled Bushmeat & $\mathrm{Ni}(\mathrm{mg} / \mathrm{kg})$ & $\mathrm{Pb}(\mathrm{mg} / \mathrm{kg})$ & $\mathrm{Cu}(\mathrm{mg} / \mathrm{kg})$ & $\mathrm{Cd}(\mathrm{mg} / \mathrm{kg})$ \\
\hline \multirow{3}{*}{$\mathrm{IL}$} & Duiker & $0.04 \pm 0.06$ & $0.03 \pm 0.02$ & $0.05 \pm 0.08$ & $0.05 \pm 0.07$ \\
& Grasscutters & $0.03 \pm 0.02$ & $0.02 \pm 0.01$ & $0.02 \pm 0.05$ & $0.03 \pm 0.05$ \\
& Monitor Lizard & $0.03 \pm 0.06$ & $0.02 \pm 0.01$ & $0.03 \pm 0.02$ & $0.04 \pm 0.03$ \\
\hline \multirow{2}{*}{$\mathrm{IF}$} & Duiker & $0.06 \pm 0.09$ & $0.06 \pm 0.06$ & $0.06 \pm 0.05$ & $0.05 \pm 0.02$ \\
& Grasscutters & $0.04 \pm 0.03$ & $0.03 \pm 0.05$ & $0.05 \pm 0.14$ & $0.03 \pm 0.01$ \\
& Monitor Lizard & $0.05 \pm 0.00$ & $0.03 \pm 0.01$ & $0.04 \pm 0.12$ & $0.05 \pm 0.02$ \\
\hline \multirow{3}{*}{$\mathrm{OS}$} & Duiker & $0.03 \pm 0.02$ & $0.03 \pm 0.02$ & $0.04 \pm 0.03$ & $0.04 \pm 0.08$ \\
& Grasscutters & $0.02 \pm 0.01$ & $0.01 \pm 0.01$ & $0.02 \pm 0.02$ & $0.02 \pm 0.05$ \\
& Monitor Lizard & $0.03 \pm 0.07$ & $0.02 \pm 0.02$ & $0.03 \pm 0.01$ & $0.03 \pm 0.07$ \\
\hline \multirow{3}{*}{$\mathrm{AL}$} & Duiker & $0.05 \pm 0.07$ & $0.05 \pm 0.05$ & $0.06 \pm 0.01$ & $0.06 \pm 0.05$ \\
& Grasscutters & $0.03 \pm 0.02$ & $0.02 \pm 0.03$ & $0.03 \pm 0.01$ & $0.04 \pm 0.02$ \\
& Monitor Lizard & $0.02 \pm 0.00$ & $0.02 \pm 0.06$ & $0.02 \pm 0.01$ & $0.04 \pm 0.00$ \\
\hline MPL(EC) & & 0.05 & 0.01 & $\mathrm{NA}$ & 0.05 \\
\hline
\end{tabular}

$\mathrm{N}$ - Sample size per bushmeat, NA - Not Available, MPL - Maximum Permissible Level, EC - European Commission, 2006.

Table 4 Analysis of Variance indicating effects of bushmeat displayed distance on concentrations of heavy metals deposition

\begin{tabular}{llccccc}
\hline & & Sum of Square & df & Mean of Square F & Sig \\
\hline Heavy metals & Between Groups & 0.013 & 3 & 0.004 & 2.595 & 0.055 \\
$\begin{array}{l}\text { concentration* } \\
\text { Locations }\end{array}$ & Within Groups & 0.232 & 140 & 0.002 & & \\
\hline & & & & & & \\
\hline
\end{tabular}

Tables 3 show the concentrations of heavy metal in the three commonly purchased bushmeat in South-western, Nigeria. Ni concentration in duiker at IF was the highest $(0.06 \pm 0.09 \mathrm{mg} / \mathrm{kg})$. This was slightly higher than the Maximum Permissible Level (MPL) recommended by European Commission. Pb concentration in all the samples was slightly higher than the recommended except grasscutter meat obtained at OS. The concentration of $\mathrm{Cu}$ was higher $(0.06 \pm 0.01 \mathrm{mg} / \mathrm{kg})$ in duiker at $\mathrm{AI}$ followed by same duiker at IL $(0.05 \pm 0.08 \mathrm{mg} / \mathrm{kg})$. Duiker at AI had highest content of $\mathrm{Cd}(0.06 \pm 0.05 \mathrm{mg} / \mathrm{kg})$ followed by duiker at IL $(0.05 \pm 0.07 \mathrm{mg} / \mathrm{kg})$ which was slightly higher than the MPL. It was evident from this study that duiker species displayed the highest concentration of $\mathrm{Ni}, \mathrm{Cu}$ and $\mathrm{Cd}$. The nearness of the bushmeat vendors to the highways is relatively proportional to the concentration of heavy metals deposition in the samples. It was observed from the oneway analysis of variance (Table 4) that distance at which these bushmeat were displayed to the highways had significant effect on the concentration of heavy metals $(\mathrm{p}<0.05)$. This finding agreed with the submission of Ndiokwere (1984) and Hafen and Brinkmann (1996) where it was mentioned that the concentrations of heavy metals decrease with increasing roadside distance. It also confirmed the position of previous studies (Ninomiya et al. 1971; Nyberg et al. 2000; Forman et al. 2003) where they mentioned that traffic intensity is one of the factors that determined deposition rate of dust from the road and that the size of dust declines with the distance from road. 


\section{CONCLUSION AND RECOMMENDATION}

It is evident from this study that most commonly patronized bushmeat on Southwestern Nigeria highways are contaminated with the studied heavy metals. Due to the fact that a wide range of factors are interacting together in the environment, it was not certain at this stage to conclude that the samples of bushmeat examined are contaminated with the selected heavy metals before or after their arrival at these bushmeat markets.

To this end, we encourage further studies to determine the concentration of such heavy meat in the carcasses of the bushmeat before they are processed. In the same vain, we encourage qualitative assessment of water available for processing these wildlife products and the surrounding air of these bushmeat markets for quality assurance.

The findings of this research work demand for appropriate institutional framework to urgently enforce that all bushmeat vendors irrespective of their geographical locations to strictly apply food safety standard.

Bushmeat sellers on those highways should be encouraged to increase the distance of their display points from the road especially where the road is unpaved and ensure that they always cover their displayed products to avoid dust deposition. Since bushmeat is of nutritional significant to man and man is an important component of ecosystem, we recommended further studies to ascertain the pathway(s) in which heavy metals contaminated these processed bushmeat to ensure safety of the consumers.

Acknowledgement: Our appreciation to the bushmeat vendors for the information and time shared with us most especially during the era of Ebola outbreak in Nigeria which created a lot of stigmatization against bushmeat.

\section{REFERENCES}

1. Adefalu LL, Adekunle AO, Aderinoye-Abdulwahab SA, Oladipo FO, Oluwafemi, AO (2014). Bushmeat consumption among urban dwellers: A major driver of wildlife hunting in Kwara State, Nigeria. The Nigerian Journal of Agriculture and Forestry, 4(1), 153-163

2. Akan JC, Abdu FI, Irahman OA, Sodipo A, Chiroma YA (2010). Distribution of heavy metals in the liver, kidney and meat of Beef, Mutton, Caprine and Chicken from Kasuwan Shanu Market in Maiduguri Metropolis, Borno State. Research Journal of Applied Sciences, Engineering and Technology, 2(8), 743-748.

3. Arima EY, Walker RT, Sales M, Souza Jr, C, Perz SG (2008). The fragmentation of space in the Amazon basin: emergent road networks, Photogrammetric Engineering and Remote Sensing, 74, 699 - 709.

4. Atayese MO, Eigbadon AI, Oluwa KA, Adesodun JK (2009). Heavy metal contamination of amaranthus grown along major highways in Lagos. African Crop Science Journal, 16, 225-235.

5. Bai J, Cui B, Wang Q, Gao H, Ding Q (2009). Assessment of heavy metal contamination of roadside soils in Southwest China. Stoch. Environ. Res. Risk Ass., 23 (3), 341-347.

6. Bowen-Jones E, Brown D, Robinson EJZ (2003). Economic commodity or environmental crisis? An interdisciplinary approach to analysing the bushmeat trade in central and west Africa. Area, 35(4), 390-402.

7. Caldas MM, Simmons C, Walker R, Perz S, Aldrich S, Pereira R, Leite F, Arima E (2010). Settlement formation and land cover use change: A case study in the Brazilian Amaon, Journal of Latin Amerian Geography, 9, 125 - 144.

8. Cambra K, Martinez T, Urzelai A, Alonso E (1999). Risk analysis of a farm area near a lead- and cadmium-contaminated industrial site. J. Soil Contam., 8, 527-540.

9. Celik A, Kartal A, Akdogan, A, Kaska Y (2005). Determination of heavy metal pollution. In Ellen, G., J. W. van Loon and K. Tolsma. (1990). Heavy metals in vegetables grown in the Netherlands and in domestic and imported fruits. Zeitschrift Lebensmittel Untersuchung Forschung, 190, 34-39.

10. Demirezen D, Urue K (2006). Comparative study of trace elements in certain fish, meat and product. Meat Sci., 74(2), 255-260. 
11. Ediagbonya TF, Tobin EA, Olumayede EG, Okungbwa GE, Iyekowa O (2016). The determination of exposure to total, inhalable and respirable particles in Welders in Benin City, Edo State. Journal of pollution control and effect, 4(1), 152-157.

12. Ediagbonya TF, Ukpebor EE, Okiemien FE, Momoh OLY (2014). Elemental Concentration and Source Identification of Inhalable and Respirable Particulate Matter in Urban Area during Wet Season. J.Appl.Sci.Environ. Manag. 18(1), 87-92.

13. Ekenma K, Anelon NJ, Ottah AA (2015). Determination of the presence and concentration of heavy metal in cattle hides singed in Nsukka abattoir. Journal of Veterinary Medicine and Animal Health, 7(1), 9-17.

14. Ericksen PJ (2008). Conceptualizing food systems for global environmental change research. Global Environmental Change 18, 234-245.

15. Fahrig L, Rytwinski T (2009). Effects on Animal Abundance: an Emperical Reveiw and Synthesis, Ecology and Society, 14, article 21

16. Farmer AM (1991). The effects of dust on vegetation and its consequences for nature conservation in Great Britain. CSD Note 57. Nature Conservancy Council, Peterborough.

17. Forman RTT, Alexander LE (1998). Roads and their major ecological effects, Annual Reviews of Ecological Systems, 29, 207 -231.

18. Forman RTT, Sperling G (2003). Road Ecology: Science and Solutions. Island Press, Washington DC.

19. Ghrefat, H, Yusuf, N (2006). Assessing Mn, Fe, Cu, Zn and Cd pollution in bottom sediments of Wadi Al-Arab Dam, Jordan.Chemosphere 65, 2114-2121.

20. Gray CW, Mclaren RG, Roberts AHC (2003). 'Atmospheric accessions of heavy metals to some New Zealand pastoral soils'. Sci. Total Environ., 305, 105-115.

21. Hafen MR, Brinkmann R (1996). Analysis of lead in soils adjacent to an interstate highway in Tampa, Florida. Environ. Geochem. Health, 18, 71-179

22. Ishizaki A, Saitoa K, Haniokab N, Narimatsub S, Kataokaa H (2010). Determination of polycyclic aromatic hydrocarbons in food samples by automated on-line in-tube solid-phase microextraction coupled with high-performance liquid chromatography-fluorescence detection. J. Chromatogra., 1217, 5555-5563.

23. Jarup L (2003). Hazards of heavy metal contamination. Br. Med. Bull., 68, 167-182.

24. Juste JF, Fa JE, Perez del val J, Castroviejo J (1995). Market dynamics of bushmeat species in Equitorial Guinea. Journal of Applied Ecology 32, 454-467.

25. Keller I, Largiader CR (2003). Recent habitat fragmentation caused by major roads leads to reduction of gene flow and loss of genetic variability in ground beetles, Proceedings of the Royal Society, 270, 417 - 423.

26. Laurance SG, Stouffer PC, Laurance WF (2004). Effects of road clearings on movement patterns of understory rainforest birds in central Amazonia. Conservation biology, 18, 1099-1109

27. Li XD, Poon CS, Pui SL (2001). Heavy metal contamination of urban soils sndstreer dusts in Hong Kong. App. Geochem., 16, 1361-1368.

28. Martin GHG (1983). Bushmeat in Nigeria as a natural resources with environmental implications. Environmental Conservation, 10, 125-132

29. Ndiokwere CL (1984). A study of heavy metal pollution from motor vehicle emissions and its effect on roadside soil, vegetation and crops in Nigeria. Environ. Pollut. 1984;7:35-42.

30. Ninomiya JS, Bergman W, Simpson BH (1971). Automotive particulate emissions. In: Proceedings of the Second International Clean Air Congress, (Eds H.M. Englund and W.T. Beery), 663-71. Academic Press, New York.

31. Nkansah MA, Ansah, JK (2014). Determination of Cd, $\mathrm{Hg}, \mathrm{As}, \mathrm{Cr}$ and $\mathrm{Pb}$ levels in meat from the Kumasi Central Abattoir. International Journal of Scientific and Research Publication, 4(8), 1-4.

32. Nyberg F, Gustavsson P, Järup L, Bellander T, Berglind N, Jakobsson R, Pershagen G (2000). Urban Air Pollution and Lung Cancer in Stockholm. Epidemiology, 7(5), 487-495.

33. Odewumi OS, Oguntuase BG, Agbelusi EA, Mamukuyomi D (2013). Loss of Biodiversity: A preliminary assessment of utilization of wild fauna resources in Ondo State. In Olajuyigbe, S.O, Coker, O. M and Olaleru, F. (eds). Sustaining the remaining tropical biodiversity. The $4^{\text {th }}$ annual Biodiversity conference of Tropical Biology Association. Pp 132-137.

34. Ogunjobi JA, Adu BW, Onadeko SA, Jayeola OB (2013). Development of captive juvenile male Grasscutters (Thryonomys swinderianus Temminck, 1827) fed with two common forage grass species in Nigeria. J. Bio-Sci. 21, 89-98.

35. Onadeko SA (1996). The reproductive ecology of the grasscutter (Thryonomys swinderianus Temminck) in captivity. A Ph.D thesis submitted to the Department of Wildlife and fisheries Management, Faculty of Agriculture and Forestry, University of Ibadan, Oyo State, Nigeria. 271pp

36. Perz SG, Cabrera L, Carvalho LA, Castillo J, Chacacanta R, Cossio RE, Solano YF, Hoelle J, Perales LM, Puerta I, Cespedes DR, Camacho IR, Silva AC (2012). Regional integration and local change: road 
paving, community connectivity and social-ecological resilience in a tri- national frontier, southwestern Amazonia, Regional Environmental Change, 12, 35 - 53

37. Perz SG, Caldas MM, Arima E, Walker R (2007). Unofficial road building in the Amazon: socioeconomic and biophysical explanations, Development and Change, 38, $529-551$

38. Pope CA, III, Dockery DW (2006). Health effects of fine particulate air pollution: Lines that connect. The Journal of Air and Waste Management Association, 56,709-742.

39. Rhind SN, Evans NP, Bellingham M, Sharpe RM, Cotinot C Mandon-Pepin B, Loup B, Sinclair, KD, Lea RG, Pocar P, Fischer B, Van der Zalm E, Hart K, Schmidt JS, Amezaga MR, Fowler PA (2010). Effects of environmental pollutants on the reproduction and welfare of ruminants. Animal, 4(7), 1227-1239.

40. Shyama Prasad Rao, R, Saptha Girish MK (2007) Road kills: assessing insect casualties using flagship taxa, Current Science, 92, 830 - 837.

41. Stołyhwo A, Sikorski Z (2005). Polycyclic aromatic hydrocarbons in smoked fish - A critical review. Food Chem., 91, 303-311

42. Suzuki K, Yabuki T, Ono Y (2008). Roadside Rhododendron pulchrum leaves as bioindicators of heavy metal pollution in traffic areas of Okayama. Japan. Environ. Monit. Asses., 149, 133-141.

43. Tee TN, Ikpa TF, Tortange V (2012). Bushmeat trade in Makurdi; implications for conservation of wildlife in Nigeria. Journal of Applied Biosciences, 52, 3704 - 3715

44. Vouk VB, Piver WT (1983). Metallic elements in fossil fuel combustion products: Amounts and form of emissions and evaluation of carcinogenicity and mutagenicity. Environ. Health Persp., 47:201-225

45. WHO (2000). Lead, In: Safety Evaluation of Certain Food Additives and Contaminants, Fifty-Fifth Meeting of the Joint FAO/WHO Expert Committee on Food Additives (JECFA), Geneva: WHO Food Additives Series, 44, World Health Organization, Geneva, 273- 312.

46. WHO (2011). Cadmium, In: Safety Evaluation of Certain Food Additives and Contaminants, Fifty-Fifth Meeting of the Joint FAO/WHO Expert Committee on Food Additives (JECFA), Geneva: WHO Food Additives Series, 46, World Health Organization, Geneva

47. Williams PG (2007). Nutrient Composition of Red Meat, available: http:// ro. Uow .edu .au / hbs papers/48, accessed, November 2013. Published online 2010 Apr 21.

48. Zurera-Cosano G, Moreno-Rojas R, Salmeron-Egea, Lora RP (1989). Heavy metal uptake from greenhouse border soils for edible vegetables. J. Sci. Food Agric., 49: 307-314.

\section{TALOŽENJE ZAGAĐUJUĆIH MATERIJA U MESU DIVLJIH ŽIVOTINJA SA PODRUČJA U BLIZINI AUTOPUTEVA U JUGOZAPADNOJ NIGERIJI}

U radu su prikazani rezultati ispitivanja taloženja zagađujućih materija u mesu divljih afričkih životinja, posebno teških metala \{kao što su nikal (Ni), olovo (Pb), bakar (Cu) i kadmijum $(\mathrm{Cd})\}$. Izvršena je procena najvećih pijaca za prodaju mesa divljih životinja sa lokacijama u blizini autoputa u pogledu udaljenosti od puta, obima saobraćaja i upotrebe zemljišta. U istraživanju je lično intervjuisano 120 kupaca kako bi se odredila vrsta mesa koja se najčešće kupuje, dok su koncentracije $\mathrm{Ni}, \mathrm{Pb}, \mathrm{Cu} i \mathrm{Cd}$ u tri najzastupljenije vrste mese određene uz pomoć Atomske Apsorpcione Spektrofotometrije. Rezultati su pokazali da je prosečna udaljenost pijace od autoputa \{na putevima Ibadan-Lagos (IL), Ibadan-Ife (IF), Ore-Sagamu (OS) i Abeokuta-Ibadan (AI)\} bila 6,70m, 3,50m i 10,20m, respektivno. Pošlo se od činjenice da je IL>OS>IF>AI. Prisustvo teških metala potvrdeno je u tri vrste mesa koje se najviše kupuje (meso divjeg pacova, meso afričkog dujker goveda i meso guštera varana). Koncentracija olova u mesu divljeg pacova na autoputu OS $(0.01 \pm 0.01 \mathrm{mg} / \mathrm{kg})$ je bila niža od maksimalnog dozvoljenog nivoa (MPL), dok su koncentracije Ni i Cd u mesu dujker goveda na autoputu IF (0,06 $\pm 0,09 \mathrm{mg} / \mathrm{kg})$ i AL (0,06 $\pm 0,05 \mathrm{mg} / \mathrm{kg})$, respektivno, bile veće od MPL. Koncentracije teških metala u mesu divljih životinja imaju statistički značajan uticaj $(p<0,05)$ na rastojanje.

Ključne reči: meso divljih afričkih životinja, teški metali, staza, autoputevi, ekotoksikologija 